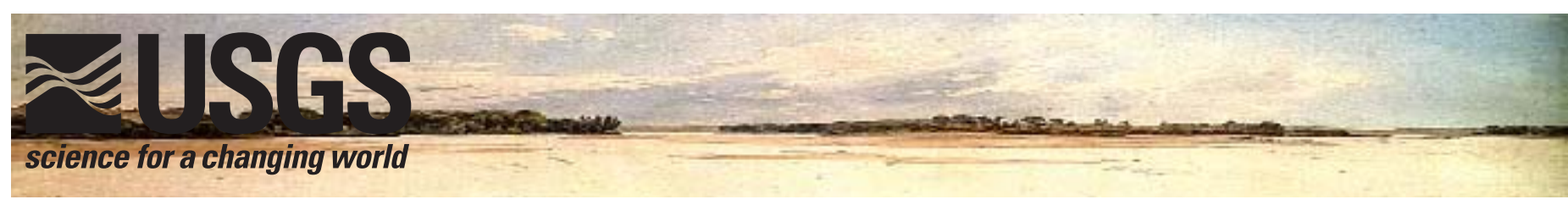

\title{
The Evolution of the Lower Missouri River: National Mapping Discipline Research at Lisbon Bottom
}

\section{Introduction}

Before 1800, the Missouri River was one of North America's most diverse and dynamic ecosystems.

During the past 200 years, civil engineering has transformed it into a navigation system regulated by reservoirs and confined by bank stabilization and flood control structures. These modifications have reduced seasonal flow variability and sediment load and have disconnected the river from backwater, off-channel, and floodplain habitats.

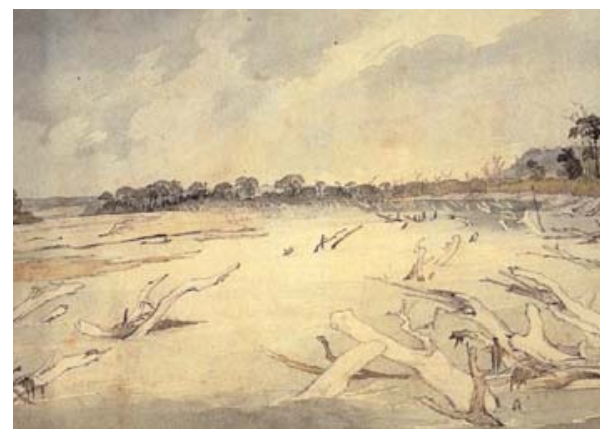

Missouri River Snags by Karl Bodmer (1833-1834).

Flooding along the Lower Missouri River in 1993 and again in 1996 created a side-channel chute across Lisbon Bottom, a well-formed loop bottom near Glasgow, Mo.

The formation and subsequent development of the chute have provided USGS scientists with a glimpse of a preregulated Missouri River.

Knowledge of geologic characteristics and processes in an alluvial setting like
Lisbon Bottom provides a scientific basis for floodplain management. This knowledge is also vital to a complete understanding of riverine habitat disturbance, recovery, and rehabilitation.

A critical component of this knowledge is an understanding of the spatial and temporal relationships between riverine habitats and geomorphic processes.

\section{Research Questions}

This project addresses three specific questions regarding the Quaternary

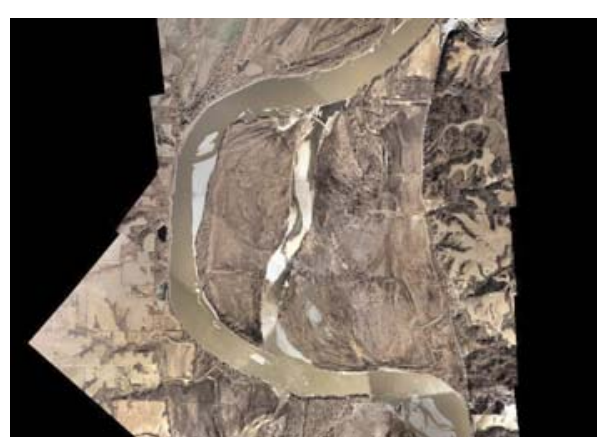

February 2000 aerial photograph of Lisbon Bottom.

geology of the lower Missouri River Valley and the relationship between the geology of the valley and terrestrial habitat along the river:

(1) What is the Quaternary history of the lower Missouri River Valley? (2) Can a general model of the lower Missouri River Valley alluvium be developed?

(3) What is the relationship between the valley's alluvial architecture and the hydrogeology of its wetlands?
Determining the architecture of the river's alluvium and the relationship between that architecture and the hydrology of the valley's wetlands will provide a more complete understanding of the relationship between the geology of the river valley and its terrestrial habitats. This will lead to a more complete understanding of habitat recovery and rehabilitation along the lower Missouri River.

\section{More Information}

Jeffrey Spooner

US Geological Survey

1400 Independence Road

Rolla, MO 65401

573-308-3526

jspooner@usgs.gov

Phyllis Altheide

US Geological Survey

1400 Independence Road

Rolla, MO 65401

573-308-3813

paltheide@usgs.gov

\section{Information}

For information on other USGS products and services, call 1-888-ASK-USGS, or visit the general interest publications Web site on mapping, geography, and related topics at erg.usgs.gov/isb/pubs/pubslists/.

For additional information, visit the ask.usgs.gov Web site or the USGS home page at www.usgs.gov. 